\title{
The Christian Universalism, Globalization and Tolerance in the Thought of Joseph Ratzinger - Benedict XVI
}

\author{
Pavol Dancak \\ Department of Philosophy and Religious Studies \\ Greek-Catholic Theological Faculty \\ University of Presov \\ St. bishop Gojdic 2 \\ Presov, Slovak Republic 08001 \\ E-mail: pavol.dancak@unipo.sk
}

\begin{abstract}
The principle of tolerance confers a right to one's own opinion, own faith and own system of values, but also the right to their manifestation. Tolerance, however, includes an appeal towards constant verification of our own opinions and towards looking for limits of tolerance. The problem of intolerance emerges. J. Ratzinger in contemplation on faith and religion in present-day world gets to the issue of tolerance, freedom, dialogue, truth and reason.
\end{abstract}

Key words—man; tolerance; faith; religion

\section{INTRODUCTION}

The principle of tolerance confers a right to one's own opinion, own faith and own system of values, but also the right to their manifestation. Tolerance, however, includes an appeal towards constant verification of our own opinions and towards looking for limits of tolerance. The problem of intolerance emerges. J. Ratzinger in contemplation on faith and religion in present-day world gets to the issue of tolerance, freedom, dialogue, truth and reason.

Religion proved to be one of the most powerful forces that have ever dominated the human history, although often paradoxically. Religion has unified tribes and races into nations, but it has also broken that integrity. Religion has built and destroyed empires. Religion has started wars, but it could also compel to peace. Religion has given birth to rich cultures and has built a spiritual barrier against the totalitarian claims of matter. It has aroused dramatic struggle in souls, but it has been a source of peace and restlessness, too. Religion has made a poor man happy. Religion has also shown the hedonists that they are the paupers. Religion has enriched the poverty of the humble and it has revealed the poverty in the hearts of the rich. And whenever any nation exterminated the religious spirit, it felled, at the same time, the roots of its own culture and life.

It is quite impossible to imagine Europe without Christianity, churches, Christian crosses lining the roads, without hospitals, human rights, solidarity and care for the weakest among us. It is evident that the civilization and culture were inspired by transcendence towards the divine. Despite that, Europe has witnessed a process of secularisation which started in the mid-last century and which has been working towards pushing God and Christianity out of all areas of human life in all ways possible. This process strived for atheistic secularism which is complete and utter exclusion of God and natural moral order from all areas of human life. Christian religion has been over and over again and with even greater vigour and subtlety restricted to private lives of individuals. Such tendencies can be seen in the Charter of Fundamental Human Rights of the European Union whose creators, contrary to historical reality, avoided any reference to God and religion.

The tolerance issue has been discussed throughout the history of philosophy, originally in connection with religious tolerance [1; P. 183]. Then it could seem that the ties between the secular and religious worlds were definitely severed. However, the religious context of tolerance has once again become apparent in today's post-secular society.

\section{ATTEMPT TO DEMARCATE TOLERANCE}

The term tolerance, from the Latin word tolerare - to put up with, endure, countenance, forbear, etc., deserves a special attention since the term itself is ambiguous, having multiple meanings ranging between acceptance and rejection, "Yes" and "No". Therefore, it is very difficult to define the tolerance and intolerance. J. Sivák says that "the value of tolerance depends on tolerated things contrary to love, when object of love does not play such a critical role: Enemy could also be loved. In this sense tolerance is not always a value. What to tolerate then? Shall we tolerate a murderer of children, an opinion or philosophy of another person or a lie of another person? Circumstances play a crucial role here. It is not only about what to tolerate but also under what circumstances and to what extent to tolerate" [2; P. 338]. According to R. Forst, a concept of tolerance is paradoxical. Tolerance is composed of both rejection and acceptance based on which the tolerated beliefs or practices are condemned as wrong or evil, but not insomuch that they 
could not be tolerated on the grounds of other positive reasons [3; P. 312-325]. Tolerance can be perceived as the most intrinsic action of man and as one of the requirements to preserve human life. As such, tolerance is an expression or a product of a particular culture and a part of a particular value system $[4 ;$ P. 18]. Such understanding of tolerance points to its meaning and limits, where the meaning can be inferred from these limits. Tolerance, in fact, is a demarcation of limits, seeking a point where something is still acceptable. When speaking of tolerance being a part of the value system, we can derive its meaning only "with respect to persons and their autonomy and not the fact whether it is favourable or utilitarian" [5; P. 6].

A primordial image demarcating limits of tolerance is described in the Book of Genesis in a story of Abram and Lot. Their herdsmen quarrelled because the land did not suffice both tribes. Abram then said to Lot: "Let there be no strife between you and me, and between your herdsmen and my herdsmen, for we are kinsmen. Is not the whole land before you? Separate yourself from me. If you take the left hand, then I will go to the right, or if you take the right hand, I will go to the left! ... Thus, they separated from each other. Abram settled in the land of Canaan, while Lot settled among the cities of the Jordan valley and moved his tents as far as Sodom" [6].

Work and activities of Joseph Ratzinger - Benedikt XVI is filled with a whole array of incentives to ponder the content of tolerance. Ratzinger as a theologian, the Pope and a representative of a community creating values, has always been taking a stand on what other people, both Catholics and the people whose values more or less differ from those of the Catholics, do and think. Thought-provoking were his various ecumenical activities and demonstrations of tolerance towards people with different views, oftentimes from a nonChristian environment.

\section{SYNTHESIS OF REASON AND FAITH}

Universalism of Christianity with its claims to the truth and morality is closely connected to the conviction that Christianity is a synthesis of reason and faith. The truth claim is on the very ground of Christian missionary service addressed to all people. At the same time, it is seen as a source of hostility and accusation of intolerance coming from the non-Christian world as if the Decalogue was a hindrance to tolerance [7; P. 26]. Contemplating this objection, Ratzinger turns to his colleague Jan Assmann, a German Egyptologist, who claimed that the monotheism of Moses entering into the polytheistic world started a distinction between true and false in religious faith and hence opened a question of idolatry and a question of worshiping the right deity [8; P. 174]. Until that very moment, Assmann maintains, religion distinguished only between the pure and impure, and between the sacrum and profanum so there was no place for false gods that people were not allowed to worship. Gods in polytheistic religions had their roles and could complement each other. Assmann proposes that the religion thinking should "return back to Egypt" where religion played a role of a mediator between cultures. The gods would be international and of a cosmic character.
Provided that there is nobody denying other gods and worship ceremonies, conditions for tolerance of opinions and peaceful coexistence could be created. Ratzinger rejects this proposal, claiming that wars between people are an image of wars portrayed in a mythical world of struggling gods and drawing attention to the human sacrifice, cast system, slavery, etc. [8; P. 174]. In this regard, St. Athanasius said that Christianity brought peace to the nations in so far as it had never been heard of [9; P. 62]. Ratzinger then refers to "the Mosaic distinction" as being identical with "Socratic distinction" [10; P. 177]. With respect to Assmann, Ratzinger claims that rejection of monotheism in the name of multicultural tolerance leads to irrationality. Referring to Patristic thinkers, however, it is evident that "the deity, to whom reason is the closest, is identical with God known from Revelation" [10; P. 178].

A difficult term "Yahweh" derives from a Hebrew root word Haja - being. This designation of God is supplemented by an explanation that the God in question is the God worshiped by the forefathers of Israel by the name of El and Elohim. Using this name the patriarchs of Israel were thus able connect to El-religion of the surrounding peoples. Their God has the attributes of being personal God (Numen Personale) and not local God (Numen Locale) [11; P. 63-78]. God is a person and not general mathematics of the universe. God is not stranded somewhere in the world as his own ghost. $\mathrm{He}$ is not some vague harmony of nature or unnameable «infinity». He is a Creator of nature, an initiator of harmony. He lives, he is the Lord [11; P. 80-81]. Ratzinger criticises the way God - Logos is being speculated on in German idealism, especially by George Wilhelm Friedrich Hegel $(1770-1831)$ and Friedrich Wilhelm Joseph von Schelling (1775 - 1854). From the Christian perspective, it is a false concept of God, Ratzinger objects, because they no longer distinguish this process of the historical self-revelation of God from a God quietly resting in himself, beyond history; history is a development of God and thus Logos is identified as a historical process. For Ratzinger, a philosophical purpose to fully comprehend the logic of the Logos leads us back to mythology of history, to the myth of God who brings himself to birth historically. The attempt at total logic ends in illogicality, in the self-dissolution of logic into myth and is completed in realization of various inhumane utopias $[11 ; \mathrm{P}$. 158].

The religious experience of people in holy places does not mean that God is bound to one place only, for He is a God of the people: Abraham, Isaac and Jacob. This God is not bound to any place, he is present everywhere. Here we see God from the perspective I and You and not from the perspective of space. This fundamental attribute of God - El remained as a principal pillar in a faith of the New Testament. The forefathers did not just chose any power, but they chose the one being above everything. The highest God is the highest Power. This God is the Promised God. He is not a natural force in which the power of nature is exposed. This God gives final meaning and purpose. He is a God of hope for the future; He shows direction [11; P. 63-78]. The fact that faith failed to make people better in their principles of thinking about nothing else but their efforts to please God 
and strive for perfection, shows that faith is exposed to a very fragile freedom. It is in fact a God's risk that is, indeed, very hard to comprehend.

The biblical concept of God distinguishes two elements. On one hand, it is an element of something personal, something intimate that one can worship. It was that element to which the fathers turned to when choosing and deciding their faith. On the other hand, one should not forget the fact that this closeness and accessibility is a free gift of the One who is beyond the space and time. Although $\mathrm{He}$ is not bound by anything, he bounds everything in Him.

The element of time extending beyond power is a recognition sign of this God. Israel utilised the second element in their efforts to convey to the other nations what was peculiar and different in their faith. Israel placed God of heaven against the particular gods and showed that their God is not a national God of Israel but God of all. A fusion of these two elements is a paradox of Biblical faith in God [11; P. 70-78].

Christian ideas appealed to more and more people and spread to new territories. The surrounding world, however, was crowded with many gods and so it was necessary to explain yet again who is that God worshiped by Christians. The early Christians were asked about the God they worshipped, but the early Church puts aside the ancient religions as deception and craze because their gods did not equal to the Highest being that was not worshipped by the ancient world, but of whom ancient philosophers spoke. The early Church justified their faith: "When speaking of God we do not worship and think of any of the gods, but we think of the being itself that philosophers refer to as an essence of all being, as God above all powers - this is our God" [11; P. 7980]. This declaration meant a decision for Logos, to choose the right path against all myths. Man chooses right when he accepts God as God and lives his life honouring God. But he is led astray towards the perversity of his own being when worshiping something that is not God; when man creates his own gods it results in worshiping only himself. In such a combination it is possible to dramatically unveil and confront various aspects of the human world [12; P. 180].

In his memorable lecture in Regensburg on 12 September 2006, Benedict XVI mentioned a 14-century dialogue between a Christian emperor and a Muslim scholar. The Christian - Islamic dialogue was carried on in 1391 in the winter barracks near Ankara during the war between the Byzantine Empire and the Turks. In such conditions, Manuel II Paleologus and the Muslim scholar discussed topics such as "Who is God?", whether it is God's desire to wage wars and forcibly convert infidels, or whether violence and actions conflicting reason conflict the God's nature, too. The emperor explicitly asks to show him just what Mohamed brought that was new and then elaborates further saying that all you will find are evil and inhuman things, using an example of spreading the faith by the sword. "God does not take pleasure in blood and not acting reasonably (syn logo) is contrary to God's nature. Faith is born of the soul, not the body. Whoever would lead someone to faith needs the ability to speak well and to reason properly, without violence and threats... To convince a reasonable soul, one does not need a strong arm or weapons of any kind, or any other means of threatening a person with death..." [13].

The foundation for this argument against violent conversations is this: not to act in accordance with reason, is contrary to God's nature. This argumentation was natural for an emperor raised in tune with Greek philosophy. Benedict XVI stresses that "essential decisions concerning the relation between faith and reason are part of the faith itself. They are a part of development keeping with the nature of the faith" [13]. For Muslim doctrine, God is absolutely transcendent and that is why some of the Muslim thinkers go as far as to state that God is not bound with rationality, God is not bound even by his own word and that nothing would oblige him to reveal the truth to us.

Human perception of God and the application of such perception to a religious practice raise a following question: could the belief that to act contrary to reason, contradicts the nature of God be applied generally, or is it just the idea applicable to ancient Greece? Here we can see a profound agreement between the Greek thinking and faith in God on Biblical basis. Evangelist and Apostle John started the Prologue to the Gospel with the opening line "In the beginning was logos", which means reason and a word. Reason expresses itself in its own rational framework. J. Ratzinger - Benedict XVI draws from the historical and cultural reality of one concrete religion having its own doctrine and an official interpretation. He considers Christian faith and Western rationality to be two partners in quest to answer questions emerging from the transcendence of man. Having said that, to satisfy one's needs does not suffice man, since he desires something that is far greater. It requires the correlation of religion and reason, as the supervisory authority of critical reason is summoned to reveal the pathology of faith (religious fundamentalism), and faith, on the other hand, is supposed to help Christians in their prophetic mission to convict the restricted reason of being irrational, for instance looking at absolute categories, such as the right to life, through the lens of utilitarian profit. Reason and truth are summoned to the dialogue in order to get cleansed and revived.

\section{TOLERANCE AND INTOLERANCE}

Ratzinger is aware of the significance attributed to the clash of religions and cultures. What should be considered here is the tolerance with respect to the peace in the world as well as the identity of a Christian who cannot abandon knowledge and proclamation of God's Word. It is also evident, that the manner in which cultural and value phenomena are exported cannot be imperial since it evokes the feeling of having one's own identity threatened [14; P. 67]. Ratzinger maintains that the authentic dialogue defining tolerance can only be carried out by a Christian who retains his own identity believing in Jesus Christ as the only Saviour. But it also means having respect for the belief of another person; with respect to the mystery of God we all strive to know. We should also be courageous enough to accept a criticism attacking our own belief [15; P. 180]. It follows that tolerance is then a normatively dependent concept. This 
means that by itself it cannot provide the substantive reasons for objections, acceptance or rejection. It needs further, independent normative sources providing a certain substance, content and limits in order to be regarded as something good in itself. Therefore, tolerance can only be a value if backed by the right normative reasons.

In the era of globalization, the issue of tolerance and intolerance of religious beliefs becomes existentially important yet again. The advancements and possibilities of science portray man as a being capable of everything he desires. Cardinal Ratzinger uses an allegory of $\mathrm{S}$. Kierkegaard's clown. In the story, a circus director sends a clown, already dressed in the costume, to inform the visitors about the fire and about the dangers of the fire being spread.

The clown tried in vain to get people out of the circus, but nobody believed him. People were laughing and the fire spread from the circus to the village and caused great damage. Cardinal Ratzinger goes on to say that the theologians are in the similar position in today's world [11; P. 12-14]. On one hand, man does not settle for what he sees, touches or hears and that is why he seeks a different way of accessing reality. On the other hand, however, he settles for his own interpretation and rejects a dialogue as a path to knowledge.

In January 2008, Benedict XVI was confronted with an incomprehensible display of intolerance and rejection of dialogue. He was invited by the rector of the La Sapienza University in Rome Renato Guarini, as well as by the members of the Academic Senate to deliver a speech Lectio Magistralis at the start of the academic year. In the end, the Pope cancelled his scheduled speech. Professor emeritus Marcello Cini wrote an open letter addressed to the rector Guarini. 67 out of 4500 academics and further 700 out of 150 thousand students sided with professor Cini [16].

Despite many people showing their disapproval of this initiative, the Pope decided not to attend the opening ceremony. Let us present two of the statements supporting the Pope: "I expect the Pope to deliver a principal and strong message and I am certain that he will still be welcome at the university," said a professor of Genetics, Bruno Dallapiccola for Vatican Radio. A Jewish professor of Mathematics Giorgio Israel also took a side of the Pope saying: "It is surprising that those who chose Voltaire's proposition "I disapprove of what you say but I will defend to the death your right to say it" as their motto, were against the Pope delivering his speech at the Rome university." It was the secularists urging the Pope and Christianity to be tolerant (professors demanded cancellation of the Pope's visit "in the name of secularity of science and culture and on the grounds of respect for our university which is open to teachers and students of any faith and ideology...") who behaved intolerably and demanded absolute acceptance of secularism [16].

Jürgen Habermas, being some kind of personification of the dialogue between the secular rationality and Christian faith, took a diametrically different stand. In his lecture in Rome, he strictly distinguished between the laicism and secularism and he rejected tendencies of the secularists as representatives of secularism that excludes faith and religion from the public space. He perceives faith as a phenomenon which cannot be simply accepted, nor can it be denied. In his lecture, he firmly rejected an opinion seeing a development of modernity as an advancement of secularization and withdrawal of religion.

He claims that "the religious communities can naturally demand their position in life of modern society. They can influence the formation of a public opinion and will, and hence come up with suitable, convincing, as well as disputable initiatives..." [16]. Habermas here expresses an idea similar to the thinking of Benedict XVI: "Listening to the great experience and findings of religious tradition of mankind, especially the Christian faith, is for philosophy and also for theology, in its own way, a source of knowledge. It would be an unacceptable restriction to our listening and responding if we ignored it." [13]. Benedict XVI also maintains: "In its very nature, the secular, "lay" character of the state comprises a balance of reason and religion that I had tried to illustrate before. However, it takes a stand against secularism as an ideology wishing to build a state of pure reason..." [17; P. 112]. Professor Habermas, who himself is an unbeliever, recognizes importance of faith and creates a space for a rational dialogue which he regards as "a path, an ideal and a choice for individuals seeking sensibleness and trying to free themselves from the power structures and interests (...) "Everybody who desire free and open public discussion support Habermas' call for a "free dialogue" [18; P. 194].

\section{CONCLUSION}

Free rational dialogue offers a space where one can reach universally acceptable synthesis of reason and faith. The Pope does not impose his opinion on everybody, he respects western secular rationality, but at the same time he requests a space for a free dialogue between such rationality and Christian faith [19; P. 62]. As a professor of Theology, he is aware of the fact that to believe means to trust in the invisible, something that we encounter in the very core of our existence. That invisible is essential for our existence and yet it is invisible [11; P. 16]. However, in the relativistic circles, his principled conviction that the politics and science are inferior to moral criteria is perceived as an opinion being referred to as politically incorrect fundamentalism.

J. Ratzinger - Benedict XVI perceives tolerance as a space for sincere, rational, free and pure demarcation of a boundary of what is acceptable. This demarcation must be hand in hand with love towards an opinion-holder whom we cannot agree with. That boundary does not mean it is hermetically sealed or separated. It should rather be understood as an appeal to openness and cooperation with those behind the boundary of toleration that we set for ourselves.

\section{REFERENCES}

[1] Czarnecki, P.: Historia filozofii. - Warszawa: Difin, 2011. 
[2] Sivák, J.: O tolerantnosti vo svetle rozpravy o cnostiach. Filozofia Vol. 65, 2010, No. 4, p. $336-342$

[3] Forst, R.: The Limits of Toleration", Constellations 11:3, 2004, p. 312-325.

[4] Dupkala, R.: Idea tolerancie - jej pôvod, význam a limity (Filozofické reflexie). In: Dupkala, R., Dudinská, I., Halčin, P. (eds.): Idea tolerancie I. - Prešov: FF PU 2013, p. 11 - 25.

[5] Mendus, S.: Toleration and the Limits of Liberalism. - London: Macmillan, 1989.

[6] Genesis, 13:1-18

[7] Stolárik, S.: Duch, sila a nádej krest’anstva. Humanum No. 5 (2) 2010 , p. $17-36$.

[8] Assmann, J.: Moses der Ägypter: Entzifferung einer Gedächtnisspur. - München-Wien 1998.

[9] Athanasius of Alexandria: On The Incarnation. - Grand Rapids: CCEL 2013.

[10] Ratzinger, J.: Wiara, prawda, tolerancja. Chrześcijaństwo a religie świata. - Kielce: Jedność, 2004.

[11] Ratzinger, J.: Úvod do krestanstva. - Brno: Petrov, 1991

[12] Králik, R. and Valc `ová, K.: The contribution of Søren Kierkegaard for the present times, in In search of meaning: current topics in philosophy and religion, KUD Apokalipsa a CERI-SK, - Ljubljana, 2014, p. 61-74.

[13] Benedikt XVI.: Lecture at the University of Regensburg. http: //tkkbs.sk/view.php?cisloclanku=20060912024 [Accessed 12. 10. 2016].

[14] Dudinská, I.: Tolerancia, intolerancia, etnocentrizmus. In: Dupkala, R., Dudinská, I., Halčin, P. (eds.): Idea tolerancie I. - Prešov: FF PU 2013, p. $64-70$.

[15] Ratzinger, J.: Granice dialogu. - Kraków 1999.

[16] Gazda, I.: Profesori kontra pápež: diktatúra okliešteného rozumu, 2008. http://www.impulzrevue.sk/article.php?277 [Accessed 12.10.2016].

[17] Ratzinger, J.: Európa. Jej základy $\mathrm{v}$ súčasnosti a $\mathrm{v}$ budúcnosti. Trnava: SSV, 2005.

[18] Matlary, J. H.: Ludské práva ohrozené mocou a relativizmom. Prešov: VMV, 2007.

[19] Rembierz, M.: Rozum a wiara - postulaty nowego dialogu i nowe kontrowersje. In: Rozum i wiara - intelektualne i duchowe dziedzictwo Jana Kantego. - Kęty: Wydawnictwo naukowe, Beskidski instytut nauk o człowieku“, 2010, p. 61 - 80. 